\title{
RESEARCH
}

Open Access

\section{Cell therapy induced regeneration of severely atrophied mandibular bone in a clinical trial}

Cecilie Gjerde ${ }^{1 *} \mathbb{D}$, Kamal Mustafa $^{1 *}$, Sølve Hellem¹, Markus Rojewski ${ }^{2,3}$, Harald Gjengedal', Mohammed Ahmed Yassin ${ }^{1,4}$, Xin Feng ${ }^{1}$, Siren Skaale ${ }^{1}$, Trond Berge ${ }^{1}$, Annika Rosen ${ }^{1}$, Xie-Qi Shi ${ }^{1}$, Aymen B. Ahmed ${ }^{5,6,7}$, Bjørn Tore Gjertsen ${ }^{5,6,7}$, Hubert Schrezenmeier ${ }^{2,3}$ and Pierre Layrolle ${ }^{8}$

\begin{abstract}
Background: Autologous grafting, despite some disadvantages, is still considered the gold standard for reconstruction of maxillofacial bone defects. The aim of this study was to evaluate bone regeneration using bone marrow-derived mesenchymal stromal cells (MSCs) in a clinical trial, a less invasive approach than autologous bone grafting. This comprehensive clinical trial included subjects with severe mandibular ridge resorption.

Methods: The study included 11 subjects aged 52-79 years with severe mandibular ridge resorption. Bone marrow cells were aspirated from the posterior iliac crest and plastic adherent cells were expanded in culture medium containing human platelet lysate. The MSCs and biphasic calcium phosphate granules as scaffolds were inserted subperiosteally onto the resorbed alveolar ridge. After 4-6 months of healing, new bone formation was assessed clinically and radiographically, as were safety and feasibility. Bone at the implant site was biopsied for microcomputed topography and histological analyses and dental implants were placed in the newly regenerated bone. Functional outcomes and patient satisfaction were assessed after 12 months.

Results: The bone marrow cells, expanded in vitro and inserted into the defect together with biphasic calcium phosphate granules, induced significant new bone formation. The regenerated bone volume was adequate for dental implant installation. Healing was uneventful, without adverse events. The patients were satisfied with the esthetic and functional outcomes. No side effects were observed.
\end{abstract}

Conclusions: The results of this comprehensive clinical trial in human subjects confirm that MSCs can successfully induce significant formation of new bone, with no untoward sequelae. Hence, this novel augmentation procedure warrants further investigation and may form the basis of a valid treatment protocol, challenging the current gold standard.

Trial registration: EudraCT, 2012-003139-50. Registered on 21 August 2013. ClinicalTrials.gov, NCT 02751125. Registered on 26 April 2016.

Keywords: Bone tissue engineering, Biphasic calcium phosphate, Dental implants, Alveolar ridge augmentation, Mesenchymal stem cells, Bone regeneration

\footnotetext{
* Correspondence: cecilie.gjerde@uib.no; kamal.mustafa@uib.no

${ }^{1}$ Institute of Clinical Dentistry, University of Bergen, Bergen, Norway

Full list of author information is available at the end of the article
}

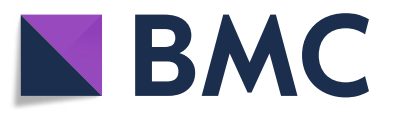

(c) The Author(s). 2018 Open Access This article is distributed under the terms of the Creative Commons Attribution 4.0 International License (http://creativecommons.org/licenses/by/4.0/), which permits unrestricted use, distribution, and reproduction in any medium, provided you give appropriate credit to the original author(s) and the source, provide a link to the Creative Commons license, and indicate if changes were made. The Creative Commons Public Domain Dedication waiver (http://creativecommons.org/publicdomain/zero/1.0/) applies to the data made available in this article, unless otherwise stated. 


\section{Background}

Bone is among the most frequently transplanted tissues, with about 2.2 million procedures annually worldwide [1]. In bone reconstruction procedures, surgeons harvest autologous bone from the patient and transplant this bone graft to the defect. This is currently regarded as the gold standard in bone regeneration, using the patient's own cells and growth factors and providing scaffolding for bone regeneration [2]. However, the procedure has several major disadvantages: harvesting requires a second surgical site and provides only limited bone stock; the two-stage procedure increases surgery time; and patients often suffer pain and nerve damage at the harvest site. Moreover, autologous bone has an unpredictable resorption rate [3-5]. These factors all increase treatment costs and patient discomfort.

In the maxillofacial region, reconstruction may be necessary to treat congenital malformations, severe facial trauma, or resection of tumors [6, 7]. Bone defects also occur in the maxilla and mandible, often after tooth loss, which results in atrophy of hard and soft alveolar tissue, and reduction of both horizontal and vertical dimensions [2]. In clinical practice, patients often present with severe alveolar ridge resorption, leaving insufficient bone volume for optimal installation of dental implants. Various surgical procedures have been developed to enlarge the alveolar crest [8].

Because of the disadvantages inherent in autologous grafting, alternative methods for bone regeneration have been proposed, including bone substitutes of animal, human, or synthetic origin [9-12]. There are, however, documented cases of infection associated with bone substitute materials. Furthermore, the risks of bacterial contamination and immune rejection of the graft must be considered [9]. While these procedures can be used to reconstruct small bone defects, they are less effective in larger defects $[3,12,13]$. Thus, there is currently an unmet clinical need for effective, safe interventions which do not expose the patient to the risk of donor site morbidity [14-18].

Multipotent stromal cells or mesenchymal stem cells (MSCs) are the cells most extensively investigated and applied [19-30]. These cells are nonhematopoietic and of mesodermal derivation, capable of self-renewal and multilineage differentiation (e.g., into osteoblasts, adipocytes, and chondrocytes). MSCs are found throughout the body and numerous extraction protocols have been established for different tissues (e.g., umbilical cord, adipose tissue, skeletal muscle, deciduous teeth, and other tissue) [20, 21, 23, 24, 31, 32]. For more than 40 years, bone marrow-derived stem cells have been the most frequent sources for cell therapy. These cells can be isolated from bone marrow and from bone chips (cortical or trabecular bone). If seeded onto or cultivated on calcium phosphate ceramic matrices in vitro, these cells can induce bone formation in vivo [14, 33-35]. For many years, biphasic calcium phosphate (BCP) has been used alone or in combination with autologous bone chips to reconstruct the floor of the maxillary sinus and to fill extraction sockets [36, 37].

Recent preclinical studies have shown that BCP ceramics consisting of $20 \%$ hydroxyapatite (HA) and $80 \%$ beta tricalcium phosphate $(\beta-\mathrm{TCP})$ are appropriate matrices for MSC culture in vitro and bone formation in vivo $[38,39]$. In the present clinical study, the maxillofacial region was selected as an appropriate site for evaluating the safety and feasibility of using MSCs and $\mathrm{BCP}$ as a new therapeutic approach to regenerate alveolar bone defects. There were several reasons for this selection. Firstly, repair of facial bone defects is a major clinical challenge [40]. Currently, therapeutic options for repairing large, critical-sized defects are limited to autografts, allografts, or transplanting vascularized bone and soft tissue from autologous secondary sites [40]. Secondly, while a functional dentition is part of the normal facial anatomy, loss of teeth initiates a process of continuous resorption of the alveolar ridge. This is accelerated by denture wear and often results in pronounced loss of bone volume and reduction in the strength of residual bone in the edentulous area. Thirdly, reconstruction of the severely atrophic mandible to restore oral function remains a difficult surgical and prosthetic challenge because of the minimal residual bony volume and the progressive nature of the resorption process [41-43]. Although only a small proportion of edentulous people need bone augmentation for implant installation, for the patients who do, the procedure is essential for restoration of oral function and treatment options are limited [10]. Finally, the implant installation procedure makes it ethically acceptable to biopsy the implant site to inspect the quality of newly formed bone.

The present clinical trial in humans introduced a novel bone augmentation protocol. The primary aim was to introduce and validate the protocol, which uses bone marrow-derived MSCs for the clinical trial and synthetic BCP in a standardized, minimally invasive surgical procedure, and to assess the feasibility, safety, and efficacy of this new procedure. The autologous cells were harvested and cultured for 3 weeks before being implanted into the defect sites. The secondary outcome was to install dental implants in the augmented alveolar bone and screw-retain a fixed partial denture on the implants.

\section{Methods}

\section{Ethical approval}

This study conforms with the Declaration of Helsinki, and was approved by the Norwegian ethical committee 
(2013/1284/REK Vest, University of Bergen) and by the Norwegian Medicines Agency (13/12062-15; EudraCT 2012-003139-50). The clinical trial followed the European guidelines for advanced therapeutic medicinal products (ClinicalTrials.gov, NCT 02751125; https://clinicaltrials.gov/ct2/show/NCT02751125).

Two experienced clinicians informed the patients about the study. After signing the consent form, the patients underwent clinical examination, including clinical photographs and dental impressions, and provided a medical history. If the patient met the inclusion criteria, cone beam computer tomography (CBCT) (Morita 3D Accuitomo F17, Japan) and dental X-ray scans were taken.

\section{Study design and participants}

Thirteen patients were recruited for this clinical study at the Section of Oral and Maxillofacial Surgery, Department of Clinical Dentistry, University of Bergen, Norway. To be eligible, the patients had to be healthy nonsmokers, with blood tests showing no evidence of infectious diseases, aged between 18 and 80 years, missing one or more teeth in the mandibular posterior region, and have an alveolar ridge width in the edentulous area less than $4.5 \mathrm{~mm}$. All participants provided written informed consent before any study-related intervention. The study design and time points for each intervention are presented in Table 1.

\section{Inclusion criteria}

- Patients presenting with a subjective indication for a fixed implant-retained prosthesis in the mandibular posterior region (i.e., distal to the canine).

- Extensive lateral bone loss of the edentulous alveolar ridge.

- Edentulous alveolar ridge width less than $4.5 \mathrm{~mm}$.

- Edentulous for more than 6 months in the region requiring reconstruction.

- At least one missing tooth to be replaced in the edentulous area.

- Absence of clinical signs of infection in the region requiring reconstruction.

- Absence of any major oral pathology.

- Age 18 years and older.

- In good health.

\section{Exclusion criteria}

- Evidence of infection with HIV, or hepatitis B or C, or any contagious disease (specifically, serologically negative for anti-HIV 1-2 Ab, anti-HCV Ab, HBs $\mathrm{Ag}$, anti-HBc syphilis, and negative (not detected by PCR) in HIV NAT, HCV NAT, or HBV NAT).

- Smoker.

- Pregnant or breastfeeding.

- Untreated infections.

- History of malignancy.

Table 1 Study design and time schedule for the intervention

\begin{tabular}{|c|c|c|c|c|c|c|c|}
\hline Intervention & $\begin{array}{l}\text { Day -21 (pre inclusion } \\
\text { visit or earlier) }\end{array}$ & Day 0 (inclusion visit) & Days $12-14$ & Month 1 & Month 6 & Month 9 & Month 18 \\
\hline $\begin{array}{l}\text { Verification of the selection criteria, } \\
\text { information given to the patient, } \\
\text { patient records and informed } \\
\text { consent obtained }\end{array}$ & $x$ & & & & & & \\
\hline Panoramic X-ray scans & $x$ & & & & $x$ & $x$ & $x$ \\
\hline Loco-regional clinical examination & $x$ & $x$ & $x$ & $x$ & $x$ & $x$ & $x$ \\
\hline Impression of both dental arches & $x$ & & & & & $x$ & \\
\hline Facial and oral cavity photographs & $x$ & & & & & & $x$ \\
\hline Dental radiographs & $x$ & & & & $x$ & $x$ & $x$ \\
\hline VAS score for pain & & & $x$ & $x$ & $x$ & $x$ & $x$ \\
\hline Questionnaire on use of painkillers & & & $x$ & $x$ & $x$ & $x$ & $x$ \\
\hline Bone marrow harvest & $x$ & & & & & & \\
\hline Grafting procedure & & $x$ & & & & & \\
\hline CBCT scan & $x$ & & $x$ & & $x$ & & $x$ \\
\hline Implant placement, bone biopsy & & & & & $x$ & & \\
\hline Resonance frequency Analysis (ISQ RFA) & & & & & $x$ & $x$ & $x$ \\
\hline Implant loading (prosthesis) & & & & & & $x$ & \\
\hline Adverse events, clinical examination & & $x$ & $x$ & $x$ & $x$ & $x$ & $x$ \\
\hline
\end{tabular}

VAS visual analog scale, CBCT cone beam computer tomography, ISQ implant stability quotient, RFA resonance frequency analysis 
- History of or scheduled cervico-facial radiation therapy.

- Chronic treatment with steroids, immunomodulatory drugs, or bisphosphonates.

\section{Cell production}

In 13 participants, bone marrow aspirates were harvested from the posterior iliac crest under local anesthesia at The Adult Clinical Trial Unit at Haukeland University Hospital, Bergen, Norway using a trocar to make two or three cutaneous punctures. Each bone marrow sample was harvested in fractions of $2-4 \mathrm{ml}$ in 20-ml syringes prefilled with 1000 IU of heparin (Leo Pharma A/S, Denmark) and sealed with a Luer lock stopper (Omnifix $20 \mathrm{ml}$ Luer Lock Solo; B. Braun Melsungen AG, Melsungen, Germany). A total of $15-20 \mathrm{ml}$ of bone marrow aspirate from each patient was transported at $21 \pm 3{ }^{\circ} \mathrm{C}$ with temperature recording and monitoring to provide traceability, and dispatched by a special courier service to the cell manufacturing center at the Institute for Clinical Transfusion Medicine and Immunogenetics (IKT), Ulm, Germany. This center has a production license for MSCs from BM aspirates (production license DE_BW_01_MIA_2013_0040/ DE_BW_01_IKT Ulm), using Good Manufacturing Practices (GMP), according to defined standard operating procedures and in compliance with the established quality management system. The advanced therapy medicinal product MSCs were manufactured at IKT Ulm as previously described by Fekete et al. [44].

On arrival in Ulm, BM aspirates from the syringes were pooled and a cell count of the bone marrow was performed using an automated hematology analyzer (Sysmex KX-21 N; Sysmex Deutschland GmbH, Norderstedt, Germany) before any manipulation. Viability was evaluated by flow cytometry following 7-amino-actinomycin D staining (FC500 flow cytometer; Beckman Coulter, USA). If the total white blood cell (WBC) count was less than $127.2 \times$ $10^{6}$ cells, the sample was considered inadequate for processing. Viability of MSCs (passage 0 and passage 1) was evaluated by Trypan blue staining (Sigma, Taufkirchen, Germany). All manipulations were conducted under laminar hood flow in grade A clean room conditions. The expansion was carried out as previously described [44]. In brief, the cell expansion started with $15-20 \mathrm{ml}$ of bone marrow aspirate; the cells were seeded on one to eight 2-chamber CellSTACKs (Corning/Fisher Scientific, Schwerte, Germany) at a density of $50,000 \mathrm{WBCs} / \mathrm{cm}^{2}$ in Minimal Essential Medium alpha modification ( $\alpha M E M)$ (Lonza, Basel, Switzerland), supplemented with 5\% human platelet lysate (PL; IKT Ulm) and $1 \mathrm{IU} / \mathrm{ml}$ heparin (Ratiopharm, Ulm, Germany) for 14 days. The cells were then detached using trypsin (TrypZEAN; Lonza). The harvested passage 0 cells (MSC-P0) were counted and reseeded on one to seven 2-chamber CellSTACKs at a density of $4000 \mathrm{MSC}-\mathrm{P0} / \mathrm{cm}^{2}$ in aMEM supplemented with $8 \%$ human platelet lysate and $1 \mathrm{IU} / \mathrm{ml}$ heparin (Ratiopharm) for 7 days. The cells were detached and passage 1 MSCs were washed with phosphate buffered saline without $\mathrm{Ca}^{2+} / \mathrm{Mg}^{2+}$ (Lonza), resuspended in a concentration of $20 \times 10^{6} \mathrm{MSCs} / \mathrm{ml}$ in clinical-grade physiological saline (Kochsalz 0.9\% INJ.-FL.(injection fluid), $50 \mathrm{ml}$; B. Braun Melsungen AG) supplemented with 4-5\% human serum albumin (CSL Behring, Munich, Germany). Doses of $5 \mathrm{ml}$ were drawn into one or two sterile syringes sealed with a Luer lock stopper. Transport was undertaken by a certified shipping company (World Courier, Stuttgart, Germany) as an accompanied transport to the clinical unit at the Department of Oral and Maxillofacial Surgery, Institute of Clinical Dentistry, University of Bergen, within $24 \mathrm{~h}$ of production. Appropriate quality controls of the cell therapy product were conducted after each step of the culture procedure. Viability and the number of cells were conducted using a Trypan blue viability test and a Countess Automated Cell Counter (Countess ${ }^{\text {rm }}$; Invitrogen, Life Technologies, USA) respectively. Details on manufacturing the MSCs including quality controls are presented in a separate manuscript (Rojewski et al., submitted).

\section{Clinical procedures}

All procedures were carried out under local anesthesia by an experienced surgeon (CG). CBCT scans were taken for each patient using a CBCT scanner (Morita 3D Accuitomo F17, Japan) to evaluate the bone volume before (T0) and 4-6 months after grafting (T1). One hour preoperatively, the patients received $1 \mathrm{~g}$ amoxicillin orally (or $300 \mathrm{mg}$ clindamycin if allergic to penicillin). The site was surgically prepared under local anesthesia (Xylocain/adrenalin 2\%; Astra Zenical AS, Sweden). A flap was raised and the cortical bone was then perforated with a small round burr, to enhance blood flow and facilitate vascular ingrowth into the biomaterials (Fig. 2A). Titanium-reinforced, nonresorbable polytetrafluoroethylene (PTFE) (Cytoplast; Osteogenics Biomedical, Lubbock, TX, USA) membranes were then fixed to the underlying bone by micro-screws and mini-screws (Biomet, Jacksonville, FL, USA) to provide a "tenting" effect [45-47].

For each patient, $5 \mathrm{~cm}^{3}$ of $\mathrm{BCP}\left(\mathrm{MBCP}^{+\mathrm{+m}}\right.$; Biomatlante, France), comprising 20\% HA and $80 \% \beta$-TCP in the form of granules $0.5-1 \mathrm{~mm}$ in size and packed in two syringes, were used and mixed with 100 million MSCs at the time of surgery. During this step, MSCs attached to the $\mathrm{BCP}$ granules in the syringes within a contact time of $60 \mathrm{~min}$. The final number of cells mixed with $\mathrm{BCP}$ was in a dose of $20 \times 10^{6}$ cells $/ 1 \mathrm{~cm}^{3}$ [39]. When the graft was ready to be inserted, the $\mathrm{BCP}$ granules loaded with MSCs were withdrawn from the syringe and immediately inserted into the implant site (Fig.2B). Part of the mixture was preserved for additional analyses, particularly 
bacteriological tests and cell attachment on $\mathrm{BCP}$. For cell attachment, the fluorescent dye DAPI (Sigma-Aldrich), which binds selectively to DNA and forms strongly fluorescent DNA-DAPI complexes, was used. The cell-seeded material was introduced into the pocket formed by the bony ridge and the regenerative membrane and then covered by the membrane and muco-periosteal flaps (Fig. 2C). Finally, the flaps were sutured to the vestibular mucosa using nonabsorbable sutures (4/0 Supramide; B. Braun Surgical SA, Spain).

The patients were instructed to eat only soft food for the next 10-14 days, and to rinse daily with chlorhexidine. The antibiotics were continued for 7 days. If necessary, pain was managed by oral administration of paracetamol (1 $\mathrm{g}$ tablets) or codeine phosphate sesquihydrate $(30 \mathrm{mg}$ ) four times per day.

The operation site was examined clinically and the sutures were removed 12 days after surgery. CBCT scans were taken of the augmented area (T1). The patients were recalled for clinical examination after 1, 2, and 4 months (Fig. 2D). CBCT scans were taken 4-6 months postoperatively to determine whether the sites were ready for implant installation.

At the time of implant installation the augmented area was reentered if the width was $7 \mathrm{~mm}$ or more (Fig. 2E). Prior to implant installation, bone biopsies were taken under local anesthesia: new bone formation was assessed by histology and micro-computed tomography ( $\mu$-CT) (Skyscan 1172; Bruker) at $40 \mathrm{kV}$ and $2.4-\mu \mathrm{m}$ voxel size. Dental implants (Bone Level, Roxolid ${ }^{\circ}$, SLActive ${ }^{\circ}$; Institut Straumann AG, Basel, Switzerland) with a diameter of $4.1 \mathrm{~mm}$ and a length of $8-10 \mathrm{~mm}$ were then installed according to the manufacturer's recommendations (Fig. 2F). Abutment surgery was done 2 months after implant installation (Fig. 2G) and a screw-retained crown was mounted 24 weeks later (Fig. $2 \mathrm{H}$ ). The implant stability quotient (ISQ) was measured at each of these procedures using an Ostell $^{\circ}$ device (Ostell AB, Gothenburg, Sweden).

\section{Bone volume measurements and $\mathrm{CBCT}$ analyses}

CBCT scans (Morita 3D Accuitomo F17, Japan) were taken before grafting (T0) and 6 months after grafting (T1), at $85 \mathrm{kVp}, 9.5 \mathrm{~mA}$ with a field of view (FOV) of $6 \mathrm{~cm} \times 6 \mathrm{~cm}$ (diameter $\times$ height), scanning time of $17.5 \mathrm{~s}$, and a voxel size of $0.125 \mathrm{~mm}$.

\section{Reconstruction of 3-dimensional models}

The DICOM files of the images were then imported to Mimics program 19.0 (Materialize NV, Leuven, Belgium). The threshold of each case was selected manually, based on subjective evaluation of the apparent display of the residual jaw bone and the graft, this defined the boundary of the region of interest (ROI) of each case. The mask of the ROI at T0 was achieved and visualized in axial, sagittal, and coronal views. The $2 \mathrm{D}$ masks were then transformed into 3D models using the so-called "calculate 3D" function. The volume in cubic millimeters of the graft models was acquired automatically with a display of a color-coded 3D model.

The superimposition of the images at $\mathrm{T} 0$ and $\mathrm{T} 1$ was applied to the Standard Tessellation Language (STL) registration method [48]. Once the models were optimally superimposed, 3D models were reconstructed from the same region in the T0 and T1 images, specifying the augmented bone volumes (ROI).

\section{Processing bone biopsies \\ Micro-computed topography analyses}

The bone biopsy specimens were maintained in 10\% buffered formalin. Selected bone biopsies were scanned with the high-resolution $\mu$-CT SkyScan1172 ${ }^{\circ}$ (SkyScan, Kontich, Belgium) with the following technical parameters: $100 \mathrm{~mA}$ and $100 \mathrm{kV}$ power intensity, copper-alumina filter and $360^{\circ}$ rotation, and pixel size or resolution for acquisition and image reconstruction of $2.7 \mu \mathrm{m}$. Images from the scanning of biopsies were reconstructed by the software NRecon ${ }^{\circ}$ (SkyScan) to obtain 2D and 3D images. CTvox (version 3.2; SkyScan) was employed to create 3D images for the biopsies. The analyzed histomorphometric parameters have been described previously [49]: bone volume (BV); tissue volume (TV); bone volumetric fraction (BV/TV); trabecular thickness (Tb.Th), the mean thickness of the trabeculae in the volume of interest (VOI); trabecular separation (Tb.Sp), the mean separation of the trabeculae in the VOI; structural model index (SMI), which gives information about the preponderance of trabecular morphology; degree of anisotropy (DA), which is the presence or absence of aligned trabeculae in a particular direction ( 1 is considered isotropic, $>1$ is considered anisotropic); and fractal dimension (FD), which indicates the complexity of the specimen surface.

\section{Histological analyses}

Fixed samples were decalcified in a $\mathrm{pH} 7.4$ solution containing $4.13 \%$ EDTA/0.2\% PFA in PBS for $96 \mathrm{~h}$ at $50{ }^{\circ} \mathrm{C}$, using an automated microwave decalcifying apparatus (KOS Histostation; Milestone Med. Corp., USA). Samples were dehydrated in an ascending series of ethanol followed by butanol in an automated dehydration station (MicromMicrotech, Lyon, France). The samples were embedded in paraffin (Histowax; Histolab, Gothenburg, Sweden). Thin histological sections ( $3 \mu \mathrm{m}$ thick) were made using a standard microtome (Leica RM2255; Leica Biosystems, Nanterre, France). The sections were stained by the Masson trichrome technique, which colors cell nuclei blue/black with hematoxylin, colors cytoplasm, muscle, and erythrocytes red using fuchsine, and colors collagen green using light green solution. 
Slides were scanned (NanoZoomer; Hamamatsu, Photonics, Hamamatsu City, Shizuoka, Japan) and observed virtually (NDP view; Hamamatsu). Histomorphometry of images was performed using ImageJ and the percentages of bone and bone marrow were calculated per area of explants. Four sections through each biopsy were analyzed and quantified.

\section{Statistical analysis}

Bone width and volume are presented as means and confidence intervals. Confidence intervals were based on formulas assuming normal distributed data. The $p$ value was calculated from a one-sample $t$ test, with 0 as the hypothesized difference. $p<0.05$ was considered statistically significant.

\section{Outcomes}

The primary outcomes of the trial were safety and feasibility of the procedure, assessed 12 months after reconstruction. In order to evaluate safety, a system was established for reporting adverse events. With guidance from the European Medicines Agency, these events were further classified into serious adverse events or serious adverse reactions. Adverse events, local (e.g., infection or hematomas) or systemic (e.g., fever or allergic reaction), were to be managed according to the Guidelines for Good Clinical Practice from the International Conference on Harmonization and the German Verordnung über klinische Versuche mit Heilmitteln. The feasibility of the procedure was evaluated on the basis of two factors: surgical manipulation of the graft and the ability to install the implants as planned.

Secondary outcomes were osseointegration of the dental implant and function of the prosthetic restoration.

\section{Results}

The final cell product consisted of fresh autologous cells (MSCs) expanded in vitro expressing the markers CD90, CD73, and CD105 and negative for CD14 and CD45, with a $90 \%$ viability rate. The product also showed strong expression of markers CD49d, CD73, CD90, and CD105; moderate expression of CD14 and CD106; and low expression of CD19, CD34, and CD45.

The viability of the cells on arrival in the operating theater was $87-90 \%$ as demonstrated using Trypan blue assay and cell counting. The mixing was undertaken in theater by the surgeon, under aseptic surgical conditions (Fig. 1A, B). Cells were mixed and attached well to the BCP granules within 60 min (Fig. 1C, D).

Between June 2014 and December 2015, 13 patients aged 52-75 years (mean 65 years) were enrolled. For 11 of the 13 patients the expansions fulfilled the release criteria and cells could be delivered to the Department of Oral and Maxillofacial Surgery in Bergen. Two expansions were stopped at passage 0 because there were insufficient bone marrow cells in the starting material for expansion (Patients 5 and 10, Table 2).

All 11 patients had uneventful healing of the augmented area, without any local infection.

No adverse events occurred during the trial period. Moreover, the soft tissues covering the augmented bone showed an increased area of keratinized gingiva, providing a healthy soft tissue profile (Fig. 2d). Finally, the amount of new bone was strongly influenced by the position of the membrane.

All 11 patients had successful ridge augmentation and an adequate amount of bone for dental implant installation (Table 3). In five patients the PTFE membrane

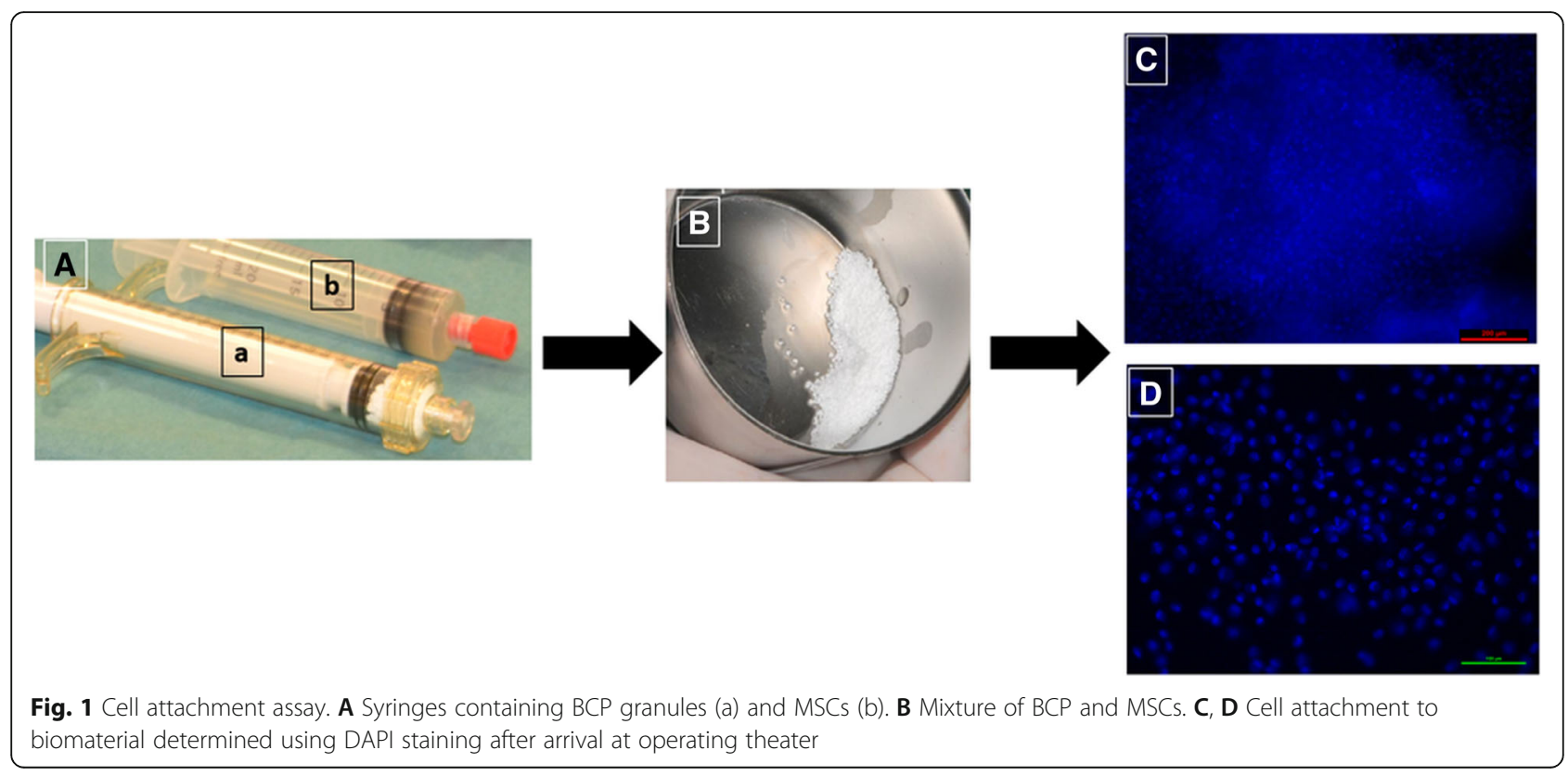


Table 2 Expansion of cells derived from bone marrow of 13 patients

\begin{tabular}{|c|c|c|c|}
\hline $\begin{array}{l}\text { Patient } \\
\text { number }\end{array}$ & $\begin{array}{l}\text { BMSCs/Hl BM } \\
\text { number of MNCs }\end{array}$ & $\begin{array}{l}\text { BMSCs/Ml BM } \\
\text { aspirate in passage } 1\end{array}$ & $\begin{array}{l}\text { Overall harvest after } \\
\text { culture passage } 1\end{array}$ \\
\hline 1 & $3.46 E+03$ & $2.98 \mathrm{E}+04$ & $3.06 \mathrm{E}+08$ \\
\hline 2 & $1.13 E+04$ & $1.52 \mathrm{E}+05$ & $4.12 \mathrm{E}+08$ \\
\hline 3 & $3.59 E+03$ & $2.89 E+04$ & $2.46 \mathrm{E}+08$ \\
\hline 4 & $1.83 E+04$ & $2.44 \mathrm{E}+05$ & $4.05 E+08$ \\
\hline 5 & $5.74 \mathrm{E}+01$ & $-{ }^{a}$ & $-{ }^{a}$ \\
\hline 6 & $4.77 E+03$ & $6.27 \mathrm{E}+04$ & $4.02 E+08$ \\
\hline 7 & $5.03 E+02$ & $5.27 \mathrm{E}+03$ & $5.33 E+07$ \\
\hline 8 & $1.61 E+03$ & $2.26 \mathrm{E}+04$ & $2.86 \mathrm{E}+08$ \\
\hline 9 & $1,64 \mathrm{E}+03$ & $1.67 \mathrm{E}+04$ & $1.55 E+08$ \\
\hline 10 & $-b$ & $-^{a}$ & $-{ }^{a}$ \\
\hline 11 & $6.54 \mathrm{E}+03$ & $7.67 E+04$ & $2.42 E+08$ \\
\hline 12 & $2.70 E+03$ & $2.85 E+04$ & $2.69 E+08$ \\
\hline 13 & $3.63 E+03$ & $2.79 \mathrm{E}+04$ & $2.34 \mathrm{E}+08$ \\
\hline Mean & $4.84 E+03$ & $6.32 \mathrm{E}+04$ & $2.74 \mathrm{E}+08$ \\
\hline SD & $4.98 E+03$ & $6.91 E+04$ & $1.04 \mathrm{E}+08$ \\
\hline
\end{tabular}

$B M S C$ bone marrow-derived mesenchymal stromal cell, $B M$ bone marrow, $M N C$ mononuclear cell, SD standard deviation

${ }^{a}$ No colony-forming unit fibroblast CFU-F growth

bInsufficient cell count became exposed and was removed uneventfully $7-8$ weeks post augmentation.

Casts of the alveolar ridge in each patient, X-ray scans, and clinical examinations demonstrated a significant increase of the total bone volume in all 11 patients after treatment (Fig. 3a, b).

Linear measurements of the width and height were performed from all CBCT scans in iView software (version 2.2.0.3. J; Morita MFG Corporation). Grafted bone could easily be distinguished from residual bone by density and structure on the scans taken immediately after the grafting procedure. As these measurements are known to be operator dependent, the measurements were all done by one specialist in oral radiology (SS) [50,51]. All patients had sufficient increase in alveolar width to have dental implants installed (Fig. 4 and Table 3). The average volume of bone increased by $887.23 \pm 365.01 \mathrm{~mm}^{3}$ (Table 3). Both the increase in width of the alveolar ridge and the increase in volume of the alveolar ridge were statistically significant. The mean increase in bone width $(n=14)$ was $4.05 \mathrm{~mm}(95 \%$ CI $2.74,5.36 ; p<0.001)$ and the mean increase in volume $(n=14)$ was $887.23 \mathrm{~mm}^{3}(95 \%$ CI 676 , 1097.98; $p<0.001)$.

Formation of mineralized tissues was evaluated by $\mu$-CT and histology from the biopsies taken during implant installation. From the $\mu$-CT scan datasets, 3D models were built for visualization (Fig. 5A). It was possible to identify
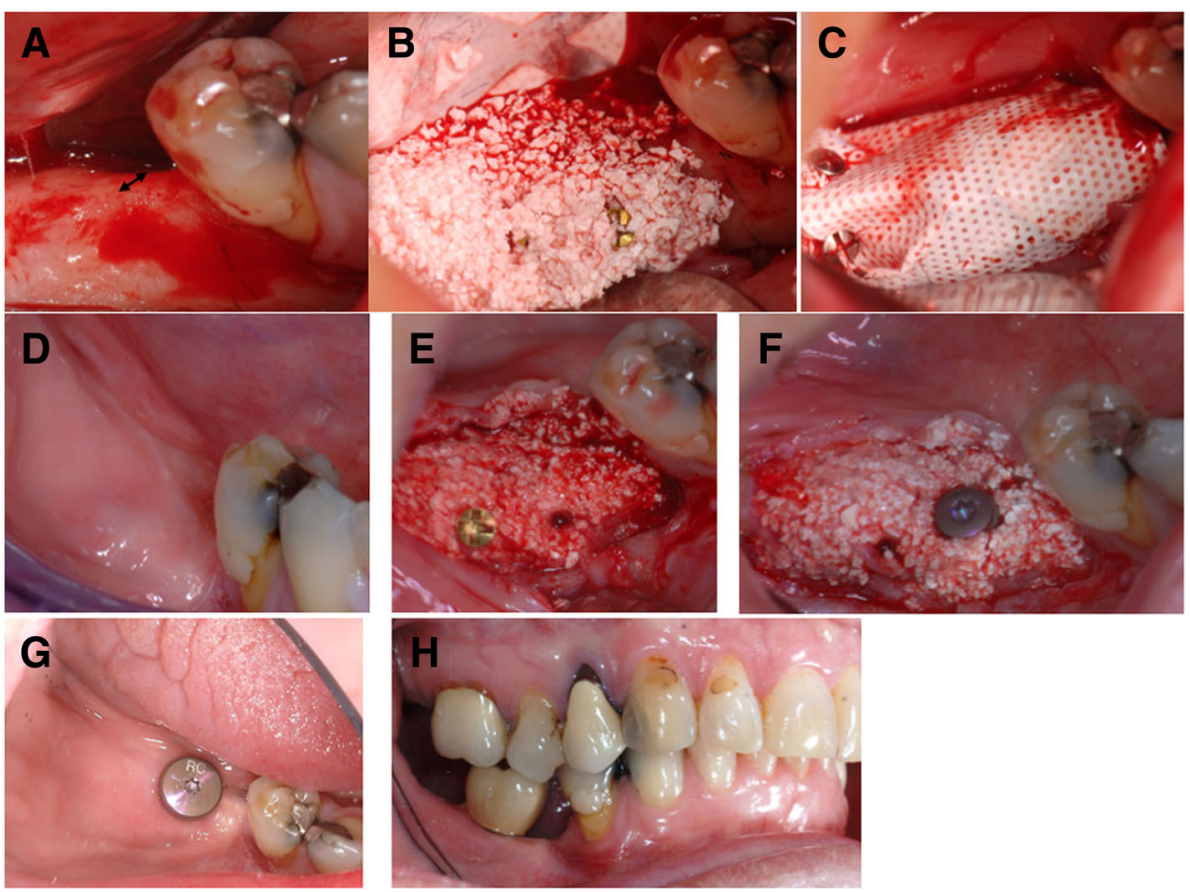

Fig. 2 Clinical procedure. a Narrow alveolar ridge before augmentation (arrow). b Mixture of BCP and MSCs placed on alveolar ridge. c Membrane placed over transplanted graft. $\mathbf{d}$ Soft tissue healing after 5 months. e New alveolar ridge after 5 months of healing. $\mathbf{f}$ Core biopsy taken and dental implant installed on newly formed bone. $\mathbf{g}$ Eight months post augmentation and 2 months after implant installation. $\mathbf{h}$ Implantsupported crown in occlusion 
Table 3 Clinical outcomes: demonstrates bone healing, increased bone width and volume

\begin{tabular}{|c|c|c|c|c|c|c|c|c|}
\hline Patient number & Age (years) & Sex & $\begin{array}{l}\text { Healing } \\
\text { time (weeks) }\end{array}$ & $\begin{array}{l}\text { Increase in } \\
\text { width (mm) }\end{array}$ & $\begin{array}{l}\text { Increase in } \\
\text { volume }\left(\mathrm{mm}^{3}\right)\end{array}$ & $\begin{array}{l}\text { Implant } \\
\text { placement }\end{array}$ & $\begin{array}{l}\text { Crown } \\
\text { delivered }\end{array}$ & $\begin{array}{l}\text { Patient } \\
\text { satisfied }\end{array}$ \\
\hline 1 & 75 & $\mathrm{~F}$ & 27 & 4.5 & 902.92 & Yes & Yes & Yes \\
\hline 2 & 67 & M & 25 & 3.7 & 1047.15 & Yes & Yes & Yes \\
\hline 3 & 55 & $F$ & 26 & 3.9 & 1382.54 & Yes & Yes & Yes \\
\hline 4 & 62 & $\mathrm{~F}$ & 18 & 1.1 & 440.93 & Yes & Yes & Yes \\
\hline 6 & 52 & M & 21 & 4.9 & 1469.53 & Yes & Yes & Yes \\
\hline 7 left & 69 & M & 31 & 4.6 & 432.7 & Yes & Yes & Yes \\
\hline 7 right & 69 & M & 31 & 4.9 & 1187.21 & Yes & Yes & Yes \\
\hline 8 & 69 & M & 22 & 1.4 & 753.52 & Yes & Yes & Yes \\
\hline 9 & 61 & $\mathrm{~F}$ & 22 & 1.4 & 546.33 & Yes & Yes & Yes \\
\hline 11 & 62 & $\mathrm{~F}$ & 21 & 9.7 & 1188.47 & Yes & Yes & Yes \\
\hline 12 left & 65 & $\mathrm{~F}$ & 20 & 2.7 & 954.98 & Yes & Yes & Yes \\
\hline 12 right & 65 & $\mathrm{~F}$ & 20 & 3.4 & 418.36 & Yes & Yes & Yes \\
\hline 13 left & 69 & $\mathrm{~F}$ & 22 & 3.7 & 553.56 & Yes & Yes & Yes \\
\hline 13 right & 69 & $\mathrm{~F}$ & 22 & 6.8 & 1142.96 & Yes & Yes & Yes \\
\hline
\end{tabular}

All patients received implants and prostheses

$F$ female, $M$ male

accurately the newly formed bone from the $\mathrm{BCP}$ granules (based on histogram calculations) when the raw data-reconstructed cross-sections were turned into images.

Histological analysis revealed that $\mathrm{BCP}$ granules were well integrated with deposition of newly formed bone tissue on the surface of the particles with osteoblast lining cells and subsequent deposition of lamellar bone tissue (Fig. 5B). The BCP granules demonstrated continuous degradation and dissolution, with the presence of multinucleated cells, probably osteoclasts, as well as macrophage $\mathrm{CD}^{+} 8^{+}$cells on the surface of the particles.

Table 4 presents the mean values for each analyzed variable obtained by $\mu$-CT analyses in relation to the microstructural properties of the biopsies.
All patients were satisfied with the esthetic and functional outcomes and no adverse events were reported or observed. There were no postoperative infections in any of the transplants or at the donor site. One patient reported moderate levels of pain after augmentation and after the exposed membrane had to be removed. The other patients reported only minor pain postoperatively. All patients were satisfied with the clinical outcome of the augmentation procedure and with their new teeth. All patients said they would recommend this procedure to others with a similar clinical condition. Ostell values increased for all patients during the first 12 months after installation of the dental implants (Fig. 6).
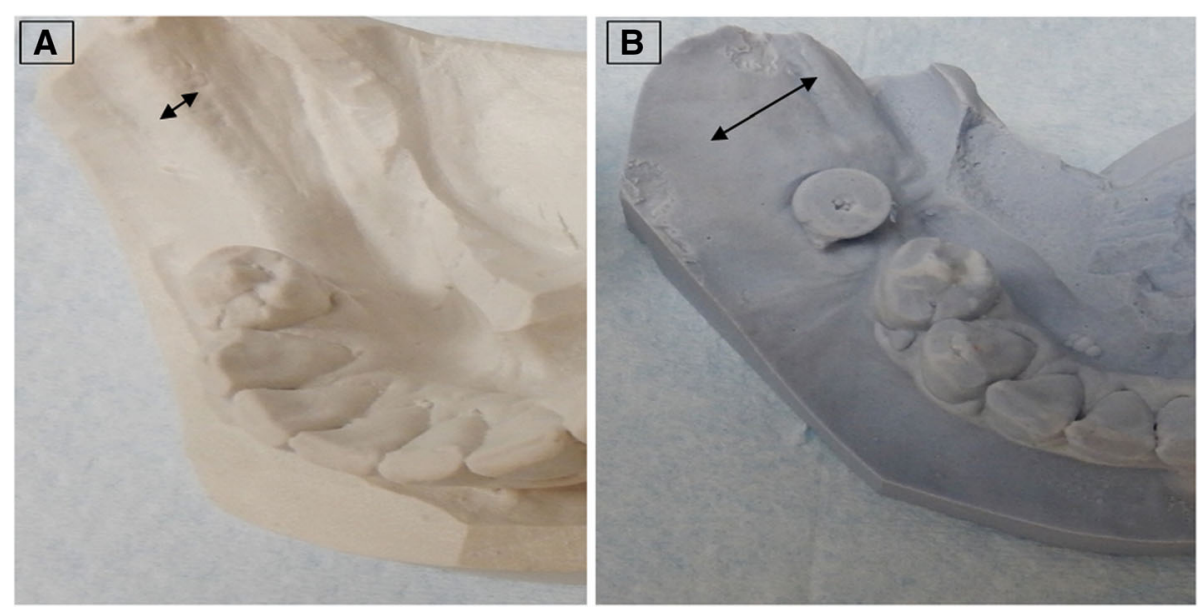

Fig. 3 Cast of alveolar ridge. Before (a) and after (b) augmentation illustrating amount of bone reconstructed. Arrows indicate the width of the alveolar ridge 


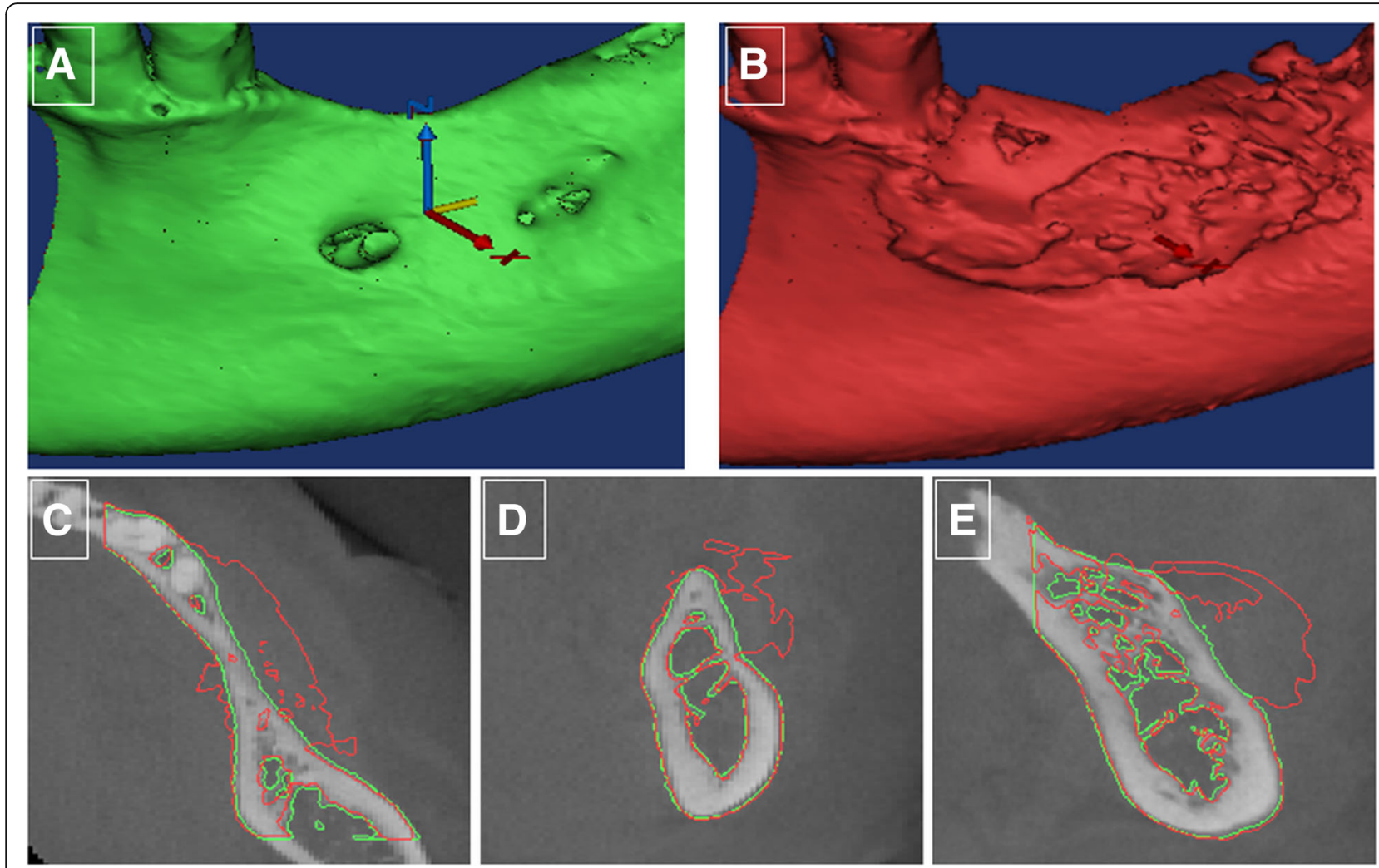

Fig. 4 CBCT measurements. Overlapping of bone outline contours of superimposed models at T0 (before grafting, green) (a) and T1 (6 months after grafting, red) (b), achieved and viewed in axial (c), sagittal (d), and coronal (e) images of ridge before and after reconstruction

\section{Discussion}

Successful augmentation of alveolar bone was observed in all study participants in this clinical trial of a novel protocol using bone marrow-derived MSCs. The site selected for bone augmentation was the posterior mandibular ridge. This is one of the most challenging sites for reconstruction, because of the relatively limited blood supply [52, 53], nonsterile environment [54], and oral functions such as chewing, speaking, and swallowing, which interfere with the stability of the graft. Despite these obstacles and the use of granules as scaffolding, we succeeded in inducing the formation of significant new bone and increasing the volume of the alveolar ridge.

Horizontal bone augmentation of the alveolar ridge is considered to be predictable, whereas vertical augmentation is not $[55,56]$. Major drawbacks in relation to the bone graft treatment are donor side morbidity, limited amount of bone to be harvested, and unpredictable resorption of the graft $[7,57-62]$. Using the stem cell/biomaterial approach in the present trial promoted both horizontal and vertical augmentation [56]. The donor site morbidity reported by the patients was minimal. The novelty of this approach was related to the development of an appropriate protocol to produce clinical-grade cells that could be used successfully for bone regeneration. The MSCs were expanded using no osteogenic factors, and no osteogenic factors were used in the clinical procedure [63-65], as growth factors may have different effects on different tissue [66] and also increase the cost of producing the cells.

In preclinical studies, MSCs were expanded and produced by the manufacturing center according to the protocol used in this clinical trial. Cells were shipped within $24 \mathrm{~h}$ and applied fresh in different animal models to demonstrate the formation of new bone in combination with the BCP biomaterial $[39,67]$ : the biomaterial alone fails to bridge bone defects in critical size calvarial defects in nude mice while full bridging was achieved with MSC/BCP combinations [39]. However, formation of bone seems to be dependent on a critical number of cells or a critical cell-to-biomaterial ratio. The number of cells and the cell-to-biomaterial $\mathrm{BCP}$ ratio used in this clinical study were adapted from the preclinical findings, where $20 \times 10^{6}$ MSCs were mixed with $1 \mathrm{~cm}^{3} \mathrm{BCP}$ [39]. We believe that the intrinsic capacity of MSCs to form bone makes the trial reproducible and safer, because the cells were not manipulated. However, a positive effect on osteogenic "predifferentiation" of MSCs using PL as a supplement during the isolation and expansion phases 

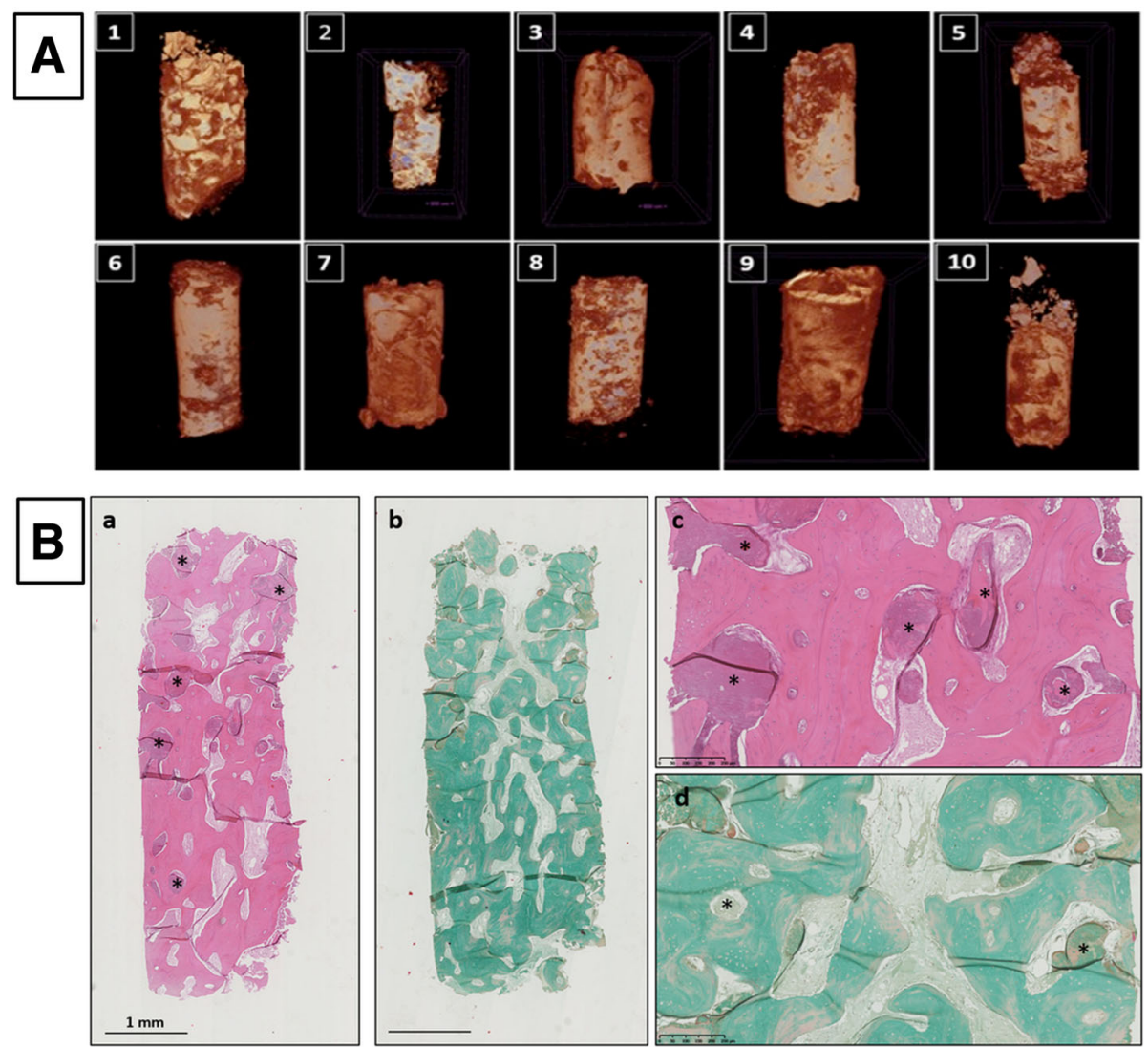

Fig. $5 \mu-C T$ and histological analyses. A $\mu-C T$ images of biopsies from Patients 1-10. B Histology of core biopsies from patients. Note abundant lamellar bone with entrapped osteocytes in extracellular matrix at high magnification around remaining BCP particles $(*)$. a, C Hematoxylin and eosin staining, b, d Masson trichrome staining. Magnification $\times 1.25$ and $\times 10$

cannot be excluded, although this has been a somewhat controversial topic $[68,69]$. In this clinical trial, PL was produced from up to 80 individual donors: as shown in a recent study, this minimizes variations in the content of growth factors, chemokines, and cytokines [44] and ensures stable conditions for the ex-vivo expansion of MSCs.

Two of the patients had insufficient cell expansion in vitro, perhaps due to the variable content of MSCs (CFU-F) in bone marrow aspirates from different

Table 4 Mean values for each analyzed variable in relation to microstructural properties of the biopsies

\begin{tabular}{lllllllll}
\hline Patient & TV $\left(\mathrm{mm}^{3}\right)$ & BV $\left(\mathrm{mm}^{3}\right)$ & BV/TV $(\%)$ & Th.Tb $(\mathrm{mm})$ & Tb.Sp $(\mathrm{mm})$ & SMl & DA & FD \\
\hline 1 & 5.187 & 1.2 & 23.131 & 0.023 & 0.131 & 0.542 & 1.153 & 2.63 \\
2 & 5.436 & 0.961 & 17.677 & 0.046 & 0.251 & 0.277 & 1.29 & 2.485 \\
3 & 4.717 & 0.495 & 10.501 & 0.004 & 0.359 & 0.742 & 1.367 & 2.256 \\
4 & 5.333 & 0.963 & 18.055 & 0.039 & 0.288 & 0.354 & 1.256 & 2.467 \\
5 & 5.358 & 0.791 & 14.762 & 0.033 & 0.279 & 0.529 & 1.107 & 2.422 \\
7 & 4.933 & 0.741 & 15.022 & 0.031 & 0.239 & 0.215 & 1.410 & 2.46 \\
8 & 5.546 & 0.881 & 15.891 & 0.045 & 0.255 & 0.812 & 1.549 & 2.46 \\
9 & 4.413 & 0.568 & 12.867 & 0.032 & 0.25 & 0.437 & 1.333 & 2.390 \\
11 & 5.064 & 1.106 & 21.844 & 0.051 & 0.180 & 0.740 & 1.144 & 2.542 \\
12 & 5.488 & 0.567 & 10.317 & 0.037 & 0.246 & 0.609 & 1.333 & 2.433 \\
\hline
\end{tabular}

In Patient 13, the biopsy disintegrated during transport and could not be measured. However, all dental implants have osseointegrated and are still in successful clinical function

$T V$ tissue volume, $B V$ bone volume, BV/TV bone volumetric fraction, Tb.Sp trabecular separation, Th.Tb Trabercular thickness, SMI structural model index, DA degree of anisotropy, $F D$ fractal dimension 


\section{Ostell Measurements}

90
80
70
60
50
40
30
20
10
0

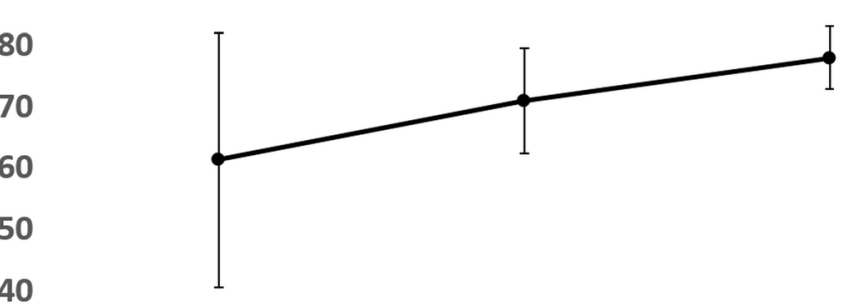

0

TO

T1

T2

Fig. 6 Ostell measurements. Implant installation (T0), at loading (T1), and at 18 months follow-up (T2). Data presented as mean \pm SD showing increased implant stability after loading

individuals [65]. This variability may be a limiting step in the procedure, but may be overcome by increasing the number of cells harvested or by developing methods for identifying the relevant cells prior to initiating culture.

There are few published papers on mandibular and maxillary defect reconstruction using bone marrow or adipose-derived stem cells [33, 70-77], many of which are case reports [70, 74, 75, 77]. The published studies vary in cell source, defect site, scaffold material, cell number, use of growth factors, and membrane or hardware $[33,70,74-79]$. However, the present data generated by treating 11 cases differ from these earlier reports as no growth factor or stimulants were used on the cells prior to implantation. Furthermore, the posterior mandibular region (i.e., distal to the canine) in all patients was selected as an inclusion criterion, as the bone healing is dependent on the location of the defected bone. Although the membrane was the determinant of augmentation volume, it complicated the surgical procedure and postoperative healing procedure. The high-density membrane is microporous, impervious to bacteria while still allowing diffusion of gases and small molecules, but probably inhibits vascularization from the periosteum, limiting the blood supply to the graft. The granules that remained outside the compartment made by the membrane did not induce bone formation, indicating the importance of using an appropriate membrane. Further supporting the importance of the membrane in bone formation, a study by Meijer et al. [76] using no membrane and grafts of bone marrow MSCs grown for 7 days in osteogenic medium and loaded with ceramic bone substitutes did not succeed in inducing bone formation.

In a randomized, controlled trial reported recently, osseous defects generated after tooth extraction were treated successfully with bone marrow-derived cells loaded on gelatin sponge. They showed accelerated healing after 6 weeks, but no significant difference after 12 weeks compared to no cells applied to the defect [33]. However, it is well known that extraction sockets heal without intervention $[58,80]$.

In the present study, the volumetric measurement on $\mathrm{CBCT}$ images was a visual protocol for assessing the outcome of grafting. The volumetric changes to the bone were achieved at $\mathrm{T} 0$ and $\mathrm{T} 1$. The objective measurement on CBCT images was performed to confirm the clinically observed volumetric changes in the graft [81-83]. This methodology has also been used in follow-up after grafting procedures in alveolar cleft patients [84-86]. Further, the biopsy specimens taken 4-6 months after augmentation showed significant new bone formation, with abundant blood supply and without inflammatory cells. The BCP scaffold was still visible in the histological samples as the reported resorption time is up to 2 years [38]. The scaffold material provides the extracellular microenvironment for support and stimulation of the cells, and also acts as the delivery system for the cells [18]. Although no direct evidence is provided relative to the source of the cells that produced the regenerated tissue (i.e., labeling of the cells), the assumption can be made that the transplanted cells at least partly contributed to bone regeneration, because the bone core specimen was taken from the central region of the defect and graft site.

Normally, there is a gradual resorption of keratinized mucosa simultaneously with bone resorption and this resorbed keratinized mucosa is known to not regenerate $[87,88]$. The presence of keratinized mucosa of at least 1-2 $\mathrm{mm}$ around an implant is beneficial in decreasing 
plaque accumulation, tissue inflammation, and attachment loss $[87,89]$. In our patients, an unexpected benefit of the augmentation procedure was an increase in the width of keratinized mucosa (Fig. 2d, g). It therefore appears that the cells used to regenerate bone also have a positive effect on neighboring soft tissues and contribute to wound healing, even when covered by a membrane. MSCs have demonstrated a beneficial effect on wound healing [90, 91]. This observation warrants further investigation. However, MSCs have demonstrated a beneficial effect on wound healing, which appears to be mediated by paracrine signaling [91]. The role of paracrine factors produced by stem cells in tissue regeneration and healing has been investigated and reports showed that angiogenesis and osteogenesis were promoted in response to the paracrine effect of stem cells $[65,90]$. This paracrine effect is exerted through cytokines and chemokines such as insulin-like growth factor (IGF)-1, vascular endothelial growth factor (VEGF), and transforming growth factor (TGF)- $\beta 1$. These growth factors were found to enhance cell proliferation, mobilization, angiogenesis, and expression of osteogenic markers such as alkaline phosphatase, collagen type I, and Runx2 genes [92]. Furthermore, these factors recruit endogenous stem cells to the grafted site [90, 92].

Because of the small cohort and follow-up time (now up to 3 years), the promising results of this study should be interpreted with caution. In order to validate this treatment protocol for application in a standard clinical setting, further study is warranted, with a larger study cohort and a longer follow-up period. Nevertheless, the results of this study are promising and could lead to the development of new strategies for regenerative medicine and therapeutic interventions, and thus have a direct and positive impact on large groups of patients.

\section{Conclusions}

The results of this novel clinical study in human subjects show that clinical reconstruction of the alveolar ridge using autologous MSCs and BCP is feasible, safe, and predictable. All sites were successfully augmented; all dental implants osseointegrated and were restored with screw-retained dental crowns as planned. Hence, this novel augmentation procedure warrants further investigation and may form the basis of a valid treatment protocol, challenging the current gold standard.

\section{Abbreviations}

BCP: Biphasic calcium phosphate; BM: Bone marrow; BV: Bone volume; BV/ TV: Bone volumetric fraction; CBCT: Cone beam computer tomography; $\mu$ CT: Micro-computed tomography; DA: Degree of anisotropy; FD: Fractal dimension; FOV: Field of view; HA: Hydroxyapatite; IGF-1: Insulin-like growth factor; ISQ: Implant stability quotient; aMEM: Minimal Essential Medium alpha modification; MSC: Mesenchymal stromal cell; PL: Platelet lysate; PTFE: Polytetrafluoroethylene; ROI: Region of interest; SMI: Structural model index; STL: Standard Tessellation Language; Tb.Sp: Trabecular separation;
Tb.Th: Trabecular thickness; $\beta$-TCP: Beta tricalcium phosphate; TGF: Transforming growth factor; TV: Tissue volume; VEGF: Vascular endothelial growth factor; VOI: Mean thickness of the trabeculae in the volume of interest; WBC: White blood cell

\section{Acknowledgements}

The authors thank head nurse Linda Ljones, radiographer Marianne Lothe, prosthodontist Christine Jonsgar (University of Bergen, Norway), and research coordinator Marianne Lehmann (Haukeland University Hospital, Bergen, Norway) for their expertise and help. They would also like to acknowledge the important contribution of the patients, without whom this study could not have been undertaken. The authors acknowledge the contribution of Endre Hellem and Daniele de Santis for valuable discussions. They also thank Prof. Kristina Arvidson Fyrberg and Prof. Michele Cottler-Fox for input to the protocol and helpful comments on the manuscript and Prof. Stein A. Lie (Biostatistician) for statistical analysis. The authors also acknowledge Jerome Amiaud for performing decalcified histology on biopsies (Inserm/University of Nantes, France).

\section{Funding}

The financial support of the European Union's Seventh Framework Programme under grant agreement number 241879_REBORNE is acknowledged. The authors also acknowledge the significant contribution by Institut Straumann AG (Basel, Switzerland) for providing the dental implants, Osteogenics Biomedical (Lubbock, TX, USA for the Cytoplast polytetrafluoroethylene membranes, and Ostell (Gothenburg, Sweden) for the Ostell device.

\section{Availability of data and materials}

The datasets generated during and/or analyzed during the current study are available from the corresponding author on reasonable request.

\section{Authors' contributions}

CG contributed to conception and design, data interpretation, patient screening, surgical treatment of the patients, manuscript writing, and final approval and was a principal investigator. KM contributed to conception and design, data interpretation, manuscript writing, final approval, and project technical and strategic management and was a principal investigator. SH contributed to conception and design, manuscript writing, administrative support, and data interpretation and was leader of the maxillo work package. MR contributed to cell production, data generation, and manuscript writing. HG contributed to conception and design, data interpretation, patient screening, and prosthetic treatment of patients. MAY contributed to $\mu-C T$ data generation, analysis, and interpretation. XF contributed to CBCT analysis. SS contributed to data interpretation and patient screening. X-QS contributed to CBCT data interpretation. TB and AR contributed to conception and design, and

manuscript writing. ABA and BTG contributed to conception and design, bone marrow acquisition, and administrative support. HS contributed to conception and design, administrative support, and data interpretation and was leader of the cell production work package. PL contributed to conception and design, data interpretation, and final approval and was coordinator of the REBORNE project with technical and strategic management, financial and budgetary management, compilation, elaboration, and communication of the official reports to the European Commission, and internal communication. All authors read and approved the final manuscript.

\section{Ethics approval and consent to participate}

This study conforms with the Declaration of Helsinki, and was approved by the Norwegian ethical committee (2013/1284/REK Vest, University of Bergen) and by the Norwegian Medicines Agency (13/12062-15; EudraCT 2012-

003139-50). The clinical trial followed the European guidelines for advanced therapeutic medicinal products (ClinicalTrials.gov, NCT 02751125, https://clinicaltrials.gov/ct2/show/NCT02751125).

All patients consented to participate in the clinical trial and to publish the data.

Consent for publication

All authors consented to publication of this manuscript.

Competing interests

The authors declare that they have no competing interests. 


\section{Publisher's Note}

Springer Nature remains neutral with regard to jurisdictional claims in published maps and institutional affiliations.

\section{Author details}

${ }^{1}$ Institute of Clinical Dentistry, University of Bergen, Bergen, Norway. ${ }^{2}$ Institute of Transfusion Medicine, Ulm University, Ulm, Germany. Institute for Clinical Transfusion Medicine and Immunogenetics Ulm, Red Cross Blood Service Baden-Württemberg-Hessen and Institute for Transfusion Medicine, University Hospital Ulm, UIm, Germany. ${ }^{4}$ Department of Fibre and Polymer Technology, KTH Royal Institute of Technology, 10044 Stockholm, Sweden. ${ }^{5}$ Department of Internal Medicine, Hematology Section, Haukeland University Hospital, Bergen, Norway. ${ }^{6}$ Centre for Cancer Biomakers CCBIO, Bergen, Norway. ${ }^{7}$ Department of Clinical Science, Precision Oncology Research Group, University of Bergen, Bergen, Norway. ${ }^{8}$ INSERM, UMR 1238, PHY-OS, Laboratory of Bone Sarcomas and Remodeling of Calcified Tissues, Faculty of Medicine, University of Nantes, Nantes, France.

Received: 19 March 2018 Revised: 1 July 2018

Accepted: 6 July 2018 Published online: 09 August 2018

\section{References}

1. Kinaci A, Neuhaus $V$, Ring DC. Trends in bone graft use in the United States. Orthopedics. 2014;37(9):e783-8. PubMed PMID: 25350620

2. Sakkas A, Wilde F, Heufelder M, Winter K, Schramm A. Autogenous bone grafts in oral implantology-is it still a "gold standard"? A consecutive review of 279 patients with 456 clinical procedures. Int J Implant Dent. 2017;3(1):23. PubMed PMID: 28573552. PMCID: PMC5453915. Epub 2017/06/03

3. Amini AR, Laurencin CT, Nukavarapu SP. Bone tissue engineering: recent advances and challenges. Crit Rev Biomed Eng. 2012;40(5):363-408. PubMed PMID: 23339648. PMCID: PMC3766369

4. Swan MC, Goodacre TE. Morbidity at the iliac crest donor site following bone grafting of the cleft alveolus. Br J Oral Maxillofac Surg. 2006:44(2):12933. PubMed PMID: 15961201

5. Felice P, Pistilli R, Lizio G, Pellegrino G, Nisii A, Marchetti C. Inlay versus onlay iliac bone grafting in atrophic posterior mandible: a prospective controlled clinical trial for the comparison of two techniques. Clin Implant Dent Relat Res. 2009;11(Suppl 1):e69-82. PubMed PMID: 19681938

6. Hall MB, Vallerand WP, Thompson D, Hartley G. Comparative anatomic study of anterior and posterior iliac crests as donor sites. J Oral Maxillofac Surg. 1991;49(6):560-3. PubMed PMID: 2037910

7. Nkenke $E$, Neukam FW. Autogenous bone harvesting and grafting in advanced jaw resorption: morbidity, resorption and implant survival. Eur J Oral Implantol. 2014;7(Suppl 2):S203-17. PubMed PMID: 24977256. Epub 2014/07/01

8. Bell RB, Blakey GH, White RP, Hillebrand DG, Molina A. Staged reconstruction of the severely atrophic mandible with autogenous bone graft and endosteal implants. J Oral Maxillofac Surg. 2002;60(10):1135-41. PubMed PMID: 12378486

9. Zimmermann G, Moghaddam A. Allograft bone matrix versus synthetic bone graft substitutes. Injury. 2011;42(Suppl 2):S16-21. PubMed PMID: 21889142. https://www.sciencedirect.com/science/article/pii/ S0020138311003020?via\%3Dihub.

10. Jensen AT, Jensen SS, Worsaae N. Complications related to bone augmentation procedures of localized defects in the alveolar ridge. A retrospective clinical study. Oral Maxillofac Surg. 2016;20(2):115-22. PubMed PMID: 26932593

11. Hernigou P. Bone transplantation and tissue engineering. Part II: bone graft and osteogenesis in the seventeenth, eighteenth and nineteenth centuries (Duhamel, Haller, Ollier and MacEwen). Int Orthop. 2015;39(1):193-204. PubMed PMID: 25408488. Epub 2014/11/20

12. Calori GM, Mazza E, Colombo M, Ripamonti C. The use of bone-graft substitutes in large bone defects: any specific needs? Injury. 2011;42(Suppl 2):S56-63. PubMed PMID: 21752369

13. Kneser U, Schaefer DJ, Polykandriotis E, Horch RE. Tissue engineering of bone: the reconstructive surgeon's point of view. J Cell Mol Med. 2006;10(1): 7-19. PubMed PMID: 16563218. PMCID: PMC3933098

14. Warnke PH, Springer IN, Wiltfang J, Acil Y, Eufinger $H$, Wehmoller $M$, et al. Growth and transplantation of a custom vascularised bone graft in a man. Lancet. 2004;364(9436):766-70. PubMed PMID: 15337402
15. Marx RE, Morales MJ. Morbidity from bone harvest in major jaw reconstruction: a randomized trial comparing the lateral anterior and posterior approaches to the ilium. J Oral Maxillofac Surg. 1988;46(3):196203. PubMed PMID: 3280759

16. Jensen SS. Bone grafting in bone repair: experimental studies. Doctoral thesis. Copenhagen: Copenhagen University Hospital; 2016.

17. Tang D, Tare RS, Yang LY, Williams DF, Ou KL, Oreffo RO. Biofabrication of bone tissue: approaches, challenges and translation for bone regeneration. Biomaterials. 2016;83:363-82. PubMed PMID: 26803405. Epub 2016/01/25

18. Black CR, Goriainov V, Gibbs D, Kanczler J, Tare RS, Oreffo RO. Bone tissue engineering. Curr Mol Biol Rep. 2015;1(3):132-40. PubMed PMID: 26618105. PMCID: PMC4654432

19. Friedenstein AJ, Petrakova KV, Kurolesova Al, Frolova GP. Heterotopic of bone marrow. Analysis of precursor cells for osteogenic and hematopoietic tissues. Transplantation. 1968;6(2):230-47. PubMed PMID: 5654088. Epub 1968/03/01

20. Kern S, Eichler H, Stoeve J, Kluter H, Bieback K. Comparative analysis of mesenchymal stem cells from bone marrow, umbilical cord blood, or adipose tissue. Stem Cells. 2006;24(5):1294-301. PubMed PMID: 16410387. Epub 2006/01/18.

21. Zuk PA, Zhu M, Ashjian P, De Ugarte DA, Huang Jl, Mizuno H, et al. Human adipose tissue is a source of multipotent stem cells. Mol Biol Cell. 2002;13(12): 4279-95. PubMed PMID: 12475952. PMCID: PMC138633. Epub 2002/12/12

22. Lee K, Chan CK, Patil N, Goodman SB. Cell therapy for bone regeneration-bench to bedside. J Biomed Mater Res B Appl Biomater. 2009;89(1):252-63. PubMed PMID: 18777578. Epub 2008/09/09

23. Lee OK, Kuo TK, Chen WM, Lee KD, Hsieh SL, Chen TH. Isolation of multipotent mesenchymal stem cells from umbilical cord blood. Blood. 2004;103(5):1669-75. PubMed PMID: 14576065. Epub 2003/10/25

24. Wang HS, Hung SC, Peng ST, Huang CC, Wei HM, Guo YJ, et al. Mesenchymal stem cells in the Wharton's jelly of the human umbilical cord. Stem Cells. 2004;22(7):1330-7. PubMed PMID: 15579650. Epub 2004/12/08

25. Friedenstein AJ, Deriglasova UF, Kulagina NN, Panasuk AF, Rudakowa SF, Luria EA, et al. Precursors for fibroblasts in different populations of hematopoietic cells as detected by the in vitro colony assay method. Exp Hematol. 1974;2(2):83-92. PubMed PMID: 4455512

26. Gjerde C, De Santi D, Dominici M, Zanotti G, Hellem S, Piccinno S, Burns J, Murgia A, Candini O, Krampera M, Nocini P, Addis A, Amiaud J, Layrolle P, Mustafa K, Veronesi E. Autologous porcine bone marrow mesenchymal cells for reconstruc- tion of a resorbed alveolar bone: a preclinical model in minipigs. Int J Stem Cell Res Ther. 2017;4(2):1-11. Epub November 29, 2017

27. Jaiswal N, Haynesworth SE, Caplan Al, Bruder SP. Osteogenic differentiation of purified, culture-expanded human mesenchymal stem cells in vitro. J Cell Biochem. 1997;64(2):295-312. PubMed PMID: 9027589. Epub 1997/02/01

28. Johnstone B, Hering TM, Caplan Al, Goldberg VM, Yoo JU. In vitro chondrogenesis of bone marrow-derived mesenchymal progenitor cells. Exp Cell Res. 1998;238(1):265-72. PubMed PMID: 9457080. Epub 1998/02/11

29. Pittenger MF, Mackay AM, Beck SC, Jaiswal RK, Douglas R, Mosca JD, et al. Multilineage potential of adult human mesenchymal stem cells. Science. 1999;284(5411):143-7. PubMed PMID: 10102814. Epub 1999/04/02

30. Caplan Al. Mesenchymal stem cells. J Orthop Res. 1991;9(5):641-50. PubMed PMID: 1870029. Epub 1991/09/01

31. Dominici M, Le Blanc K, Mueller I, Slaper-Cortenbach I, Marini F, Krause D, et al. Minimal criteria for defining multipotent mesenchymal stromal cells. The International Society for Cellular Therapy position statement. Cytotherapy. 2006;8(4):315-7. PubMed PMID: 16923606

32. Le BQ, Nurcombe V, Cool SM, van Blitterswijk CA, de Boer J, LaPointe VLS. The Components of Bone and What They Can Teach Us about Regeneration. Materials. 2018;11(1):14. https://doi.org/10.3390/ma11010014.

33. Kaigler D, Pagni G, Park CH, Braun TM, Holman LA, Yi E, et al. Stem cell therapy for craniofacial bone regeneration: a randomized, controlled feasibility trial. Cell Transplant. 2013;22(5):767-77. PubMed PMID: 22776413. PMCID: PMC4100608

34. Friedenstein AJ, Chailakhjan RK, Lalykina KS. The development of fibroblast colonies in monolayer cultures of guinea-pig bone marrow and spleen cells. Cell Tissue Kinet. 1970;3(4):393-403. PubMed PMID: 5523063. Epub 1970/10/01

35. Friedenstein A, Kuralesova Al. Osteogenic precursor cells of bone marrow in radiation chimeras. Transplantation. 1971;12(2):99-108. PubMed PMID: 4936756. Epub 1971/08/01

36. Taschieri S, Corbella S, Weinstein R, Di Giancamillo A, Mortellaro C, Del Fabbro M. Maxillary sinus floor elevation using platelet-rich plasma 
combined with either biphasic calcium phosphate or deproteinized bovine bone. J Craniofac Surg. 2016;27(3):702-7. PubMed PMID: 27046471

37. Mordenfeld A, Lindgren C, Hallman M. Sinus floor augmentation using Straumann(R) BoneCeramic and bio-Oss(R) in a split mouth design and later placement of implants: a 5-year report from a longitudinal study. Clin Implant Dent Relat Res. 2016;18(5):926-36. PubMed PMID: 26358740

38. Arinzeh TL, Tran T, McAlary J, Daculsi G. A comparative study of biphasic calcium phosphate ceramics for human mesenchymal stem-cell-induced bone formation. Biomaterials. 2005;26(17):3631-8. PubMed PMID: 15621253

39. Brennan MA, Renaud A, Amiaud J, Rojewski MT, Schrezenmeier H, Heymann $D$, et al. Pre-clinical studies of bone regeneration with human bone marrow stromal cells and biphasic calcium phosphate. Stem Cell Res Ther. 2014;5(5): 114. PubMed PMID: 25311054 . PMCID: PMC4445278

40. Gronthos $\mathrm{S}$. Reconstruction of human mandible by tissue engineering. Lancet. 2004:364(9436):735-6. PubMed PMID: 15337383

41. Atwood DA. Some clinical factors related to rate of resorption of residual ridges. 1962. J Prosthet Dent. 2001;86(2):119-25. PubMed PMID: 11514795

42. Atwood DA. Reduction of residual ridges: a major oral disease entity. $J$ Prosthet Dent. 1971;26(3):266-79. PubMed PMID: 4934947

43. Tallgren A. The continuing reduction of the residual alveolar ridges in complete denture wearers: a mixed-longitudinal study covering 25 years. 1972. J Prosthet Dent. 2003;89(5):427-35. PubMed PMID: 12806317

44. Fekete N, Rojewski MT, Furst D, Kreja L, Ignatius A, Dausend J, et al. GMPcompliant isolation and large-scale expansion of bone marrow-derived MSC. PLoS One. 2012;7(8):e43255. PubMed PMID: 22905242. PMCID: PMC3419200

45. Le B, Rohrer MD, Prasad HS. Screw "tent-pole" grafting technique for reconstruction of large vertical alveolar ridge defects using human mineralized allograft for implant site preparation. J Oral Maxillofac Surg. 2010;68(2):428-35. PubMed PMID: 20116718

46. Marx RE, Shellenberger T, Wimsatt J, Correa P. Severely resorbed mandible: predictable reconstruction with soft tissue matrix expansion (tent pole) grafts. J Oral Maxillofac Surg. 2002;60(8):878-88. discussion 888-9. PubMed PMID: 12149731

47. Buser D, Dula K, Belser UC, Hirt HP, Berthold H. Localized ridge augmentation using guided bone regeneration. II. Surgical procedure in the mandible. Int J Periodontics Restorative Dent. 1995;15(1):10-29. PubMed PMID: 7591520

48. Ahmad R, Abu-Hassan MI, Li Q, Swain MV. Three dimensional quantification of mandibular bone remodeling using standard tessellation language registration based superimposition. Clin Oral Implants Res. 2013;24(11): 1273-9. PubMed PMID: 22862429

49. Hildebrand T, Rüegsegger P. A new method for the model-independent assessment of thickness in three-dimensional images. J Microsc. 1997; 185(1):67-75

50. Pinsky HM, Dyda S, Pinsky RW, Misch KA, Sarment DP. Accuracy of threedimensional measurements using cone-beam CT. Dentomaxillofac Radiol. 2006;35(6):410-6. PubMed PMID: 17082331

51. Alerico FA, Bernardes SR, Fontao FN, Diez GF, Alerico JH, Claudino M. Prospective tomographic evaluation of autogenous bone resorption harvested from mandibular ramus in atrophic maxilla. J Craniofac Surg. 2014;25(6):e543-6. PubMed PMID: 25364976

52. McGregor $A D, M a c D o n a l d ~ D G$. Age changes in the human inferior alveolar artery—a histological study. Br J Oral Maxillofac Surg. 1989;27(5):371-4. PubMed PMID: 2804039

53. Garg AK. Bone biology harvesting, and grafting for dental implants: rationale and clinical applications. 2004. ISBN 0-86715-441-1. Quintessence books.

54. Marsh PD, Percival RS. The oral microflora-friend or foe? Can we decide? Int Dent J. 2006;56(4 Suppl 1):233-9. PubMed PMID: 16972398

55. Chiapasco M, Casentini P, Zaniboni M. Bone augmentation procedures in implant dentistry. Int J Oral Maxillofac Implants. 2009;24(Suppl):237-59. PubMed PMID: 19885448

56. Esposito M, Grusovin MG, Felice P, Karatzopoulos G, Worthington HV, Coulthard $\mathrm{P}$. The efficacy of horizontal and vertical bone augmentation procedures for dental implants—a Cochrane systematic review. Eur J Oral Implantol. 2009;2(3):167-84. PubMed PMID: 20467628

57. Aghaloo TL, Moy PK. Which hard tissue augmentation techniques are the most successful in furnishing bony support for implant placement? Int J Oral Maxillofac Implants. 2007;22(Suppl):49-70. PubMed PMID: 18437791
58. Atieh MA, Alsabeeha NH, Payne AG, Duncan W, Faggion CM, Esposito M. Interventions for replacing missing teeth: alveolar ridge preservation techniques for dental implant site development. Cochrane Database Syst Rev. 2015;5:CD010176. PubMed PMID: 26020735. Epub 2015/05/29

59. Barone A, Ricci M, Mangano F, Covani U. Morbidity associated with iliac crest harvesting in the treatment of maxillary and mandibular atrophies: a 10-year analysis. J Oral Maxillofac Surg. 2011;69(9):2298-304. PubMed PMID: 21470738

60. Esposito M, Grusovin MG, Felice P, Karatzopoulos G, Worthington HV, Coulthard P. Interventions for replacing missing teeth: horizontal and vertical bone augmentation techniques for dental implant treatment. Cochrane Database Syst Rev. 2009;:CD003607. PubMed PMID: 19821311

61. Milinkovic I, Cordaro L. Are there specific indications for the different alveolar bone augmentation procedures for implant placement? A systematic review. Int J Oral Maxillofac Surg. 2014;43(5):606-25. PubMed PMID: 24451333

62. Gomez-Barrena E, Rosset P, Lozano D, Stanovici J, Ermthaller C, Gerbhard F. Bone fracture healing: cell therapy in delayed unions and nonunions. Bone. 2015;70:93-101. PubMed PMID: 25093266. Epub 2014/08/06

63. Faia-Torres AB, Charnley M, Goren T, Guimond-Lischer S, Rottmar M, Maniura-Weber $\mathrm{K}$, et al. Osteogenic differentiation of human mesenchymal stem cells in the absence of osteogenic supplements: a surface-roughness gradient study. Acta Biomater. 2015;28:64-75. PubMed PMID: 26432440

64. Bianco P, Cao X, Frenette PS, Mao JJ, Robey PG, Simmons PJ, et al. The meaning, the sense and the significance: translating the science of mesenchymal stem cells into medicine. Nat Med. 2013;19(1):35-42. PubMed PMID: 23296015. PMCID: PMC3998103

65. Raynaud CM, Rafii A. The necessity of a systematic approach for the use of MSCs in the clinical setting. Stem Cells Int. 2013;2013:892340. PubMed PMID: 23864866. PMCID: PMC3705875

66. James AW, LaChaud G, Shen J, Asatrian G, Nguyen V, Zhang X, et al. A review of the clinical side effects of bone morphogenetic protein-2. Tissue Eng Part B Rev. 2016;22(4):284-97. PubMed PMID: 26857241

67. Veronesi E, Murgia A, Caselli A, Grisendi G, Piccinno MS, Rasini V, et al. Transportation conditions for prompt use of ex vivo expanded and freshly harvested clinical-grade bone marrow mesenchymal stromal/stem cells for bone regeneration. Tissue Eng Part C Methods. 2014;20(3):239-51. PubMed PMID: 23845029. PMCID: PMC3936497

68. Xia W, Li H, Wang Z, Xu R, Fu Y, Zhang X, et al. Human platelet lysate supports ex vivo expansion and enhances osteogenic differentiation of human bone marrow-derived mesenchymal stem cells. Cell Biol Int. 2011; 35(6):639-43. PubMed PMID: 21235529

69. Shanbhag S, Stavropoulos A, Suliman S, Hervig T, Mustafa K. Efficacy of humanized mesenchymal stem cell cultures for bone tissue engineering: a systematic review with a focus on platelet derivatives. Tissue Eng Part B Rev. 2017;23(6):552-69. PubMed PMID: 28610481.

70. Sandor GK, Numminen J, Wolff J, Thesleff T, Miettinen A, Tuovinen VJ, et al. Adipose stem cells used to reconstruct 13 cases with cranio-maxillofacial hard-tissue defects. Stem Cells Transl Med. 2014;3(4):530-40. PubMed PMID: 24558162. PMCID: PMC3973720

71. Marcacci M, Kon E, Moukhachev V, Lavroukov A, Kutepov S, Quarto R, et al. Stem cells associated with macroporous bioceramics for long bone repair: 6- to 7-year outcome of a pilot clinical study. Tissue Eng. 2007;13(5):947-55. PubMed PMID: 17484701

72. Klijn RJ, Meijer GJ, Bronkhorst EM, Jansen JA. Sinus floor augmentation surgery using autologous bone grafts from various donor sites: a meta-analysis of the total bone volume. Tissue Eng Part B Rev. 2010;16(3):295-303. PubMed PMID: 19958168

73. Thesleff T, Lehtimaki K, Niskakangas T, Huovinen S, Mannerstrom B, Miettinen S, et al. Cranioplasty with adipose-derived stem cells, beta-tricalcium phosphate granules and supporting mesh: six-year clinical follow-up results. Stem Cells Transl Med. 2017;6(/):1576-83. PubMed PMID: 28504874. Epub 2017/05/16.

74. Wolff J, Sandor GK, Miettinen A, Tuovinen VJ, Mannerstrom B, Patrikoski M, et al. GMP-level adipose stem cells combined with computer-aided manufacturing to reconstruct mandibular ameloblastoma resection defects: experience with three cases. Ann Maxillofac Surg. 2013;3(2):114-25. PubMed PMID: 24205470. PMCID: PMC3814659

75. Sandor GK, Tuovinen VJ, Wolff J, Patrikoski M, Jokinen J, Nieminen E, et al. Adipose stem cell tissue-engineered construct used to treat large anterior mandibular defect: a case report and review of the clinical application of good 
manufacturing practice-level adipose stem cells for bone regeneration. J Oral Maxillofac Surg. 2013;71(5):938-50. PubMed PMID: 23375899

76. Meijer GJ, de Bruijn JD, Koole R, van Blitterswijk CA. Cell based bone tissue engineering in jaw defects. Biomaterials. 2008;29(21):3053-61. PubMed PMID: 18433864. Epub 2008/04/25

77. Rajan A, Eubanks E, Edwards S, Aronovich S, Travan S, Rudek I, et al. Optimized cell survival and seeding efficiency for craniofacial tissue engineering using clinical stem cell therapy. Stem Cells Transl Med. 2014; 3(12):1495-503. PubMed PMID: 25378653. PMCID: PMC4250207

78. Mesimaki K, Lindroos B, Tornwall J, Mauno J, Lindqvist C, Kontio R, et al. Novel maxillary reconstruction with ectopic bone formation by GMP adipose stem cells. Int J Oral Maxillofac Surg. 2009;38(3):201-9. PubMed PMID: 19168327

79. Kulakov AA, Goldshtein DV, Grigoryan AS, Rzhaninova AA, Alekseeva IS, Arutyunyan IV, et al. Clinical study of the efficiency of combined cell transplant on the basis of multipotent mesenchymal stromal adipose tissue cells in patients with pronounced deficit of the maxillary and mandibulary bone tissue. Bull Exp Biol Med. 2008;146(4):522-5. PubMed PMID: 19489333. Epub 2009/06/06

80. Hammerle CH, Chen ST, Wilson TG Jr. Consensus statements and recommended clinical procedures regarding the placement of implants in extraction sockets. Int J Oral Maxillofac Implants. 2004;19(Suppl):26-8. PubMed PMID: 15635943

81. Ludlow JB, Ivanovic M. Comparative dosimetry of dental CBCT devices and 64-slice CT for oral and maxillofacial radiology. Oral Surg Oral Med Oral Pathol Oral Radiol Endod. 2008;106(1):106-14. PubMed PMID: 18504152. Epub 2008/05/28

82. Chau AC, Fung K. Comparison of radiation dose for implant imaging using conventional spiral tomography, computed tomography, and cone-beam computed tomography. Oral Surg Oral Med Oral Pathol Oral Radiol Endod. 2009;107(4):559-65. PubMed PMID: 19168378

83. Loubele M, Bogaerts R, Van Dijck E, Pauwels R, Vanheusden S, Suetens P, et al. Comparison between effective radiation dose of CBCT and MSCT scanners for dentomaxillofacial applications. Eur J Radiol. 2009;71(3):461-8. PubMed PMID: 18639404

84. Oberoi S, Chigurupati R, Gill P, Hoffman WY, Vargervik K. Volumetric assessment of secondary alveolar bone grafting using cone beam computed tomography. Cleft Palate Craniofac J. 2009;46(5):503-11. PubMed PMID: 19929098. Epub 2009/11/26

85. Xiao WL, Zhang DZ, Chen XJ, Yuan C, Xue LF. Osteogenesis effect of guided bone regeneration combined with alveolar cleft grafting: assessment by cone beam computed tomography. Int J Oral Maxillofac Surg. 2016;45(6): 683-7. PubMed PMID: 26876144. Epub 2016/02/16

86. Janssen NG, Schreurs R, Bittermann GKP, Borstlap WA, Koole R, Meijer GJ, et al. A novel semi-automatic segmentation protocol for volumetric assessment of alveolar cleft grafting procedures. J Craniomaxillofac Surg. 2017:45(5):685-9. PubMed PMID: 28336322. Epub 2017/03/25

87. Bassetti RG, Stahli A, Bassetti MA, Sculean A. Soft tissue augmentation procedures at second-stage surgery: a systematic review. Clin Oral Investig. 2016:20(7):1369-87. PubMed PMID: 27041111.

88. Wennstrom J. Regeneration of gingiva following surgical excision. A clinical study. J Clin Periodontol. 1983;10(3):287-97. PubMed PMID: 6192155

89. Lin GH, Chan HL, Wang HL. The significance of keratinized mucosa on implant health: a systematic review. J Periodontol. 2013;84(12):1755-67. PubMed PMID: 23451989

90. Fujio M, Xing Z, Sharabi N, Xue Y, Yamamoto A, Hibi H, et al. Conditioned media from hypoxic-cultured human dental pulp cells promotes bone healing during distraction osteogenesis. J Tissue Eng Regen Med. 2015; 11(7):2116-26. PubMed PMID: 26612624

91. Hanson SE. Mesenchymal stem cells: a multimodality option for wound healing. Adv Wound Care (New Rochelle). 2012;1 (4):153-8. PubMed PMID: 24527297. PMCID: PMC3839012

92. Osugi M, Katagiri W, Yoshimi R, Inukai T, Hibi H, Ueda M. Conditioned media from mesenchymal stem cells enhanced bone regeneration in rat calvarial bone defects. Tissue Eng Part A. 2012;18(13-14):1479-89. PubMed PMID: 22443121. PMCID: PMC3397118

\section{Ready to submit your research? Choose BMC and benefit from:}

- fast, convenient online submission

- thorough peer review by experienced researchers in your field

- rapid publication on acceptance

- support for research data, including large and complex data types

- gold Open Access which fosters wider collaboration and increased citations

- maximum visibility for your research: over $100 \mathrm{M}$ website views per year

At BMC, research is always in progress.

Learn more biomedcentral.com/submissions 